Article

\title{
Review of the Low-Enthalpy Lower Cretaceous Geothermal Energy Resources in Poland as an Environmentally Friendly Source of Heat for Urban District Heating Systems
}

\author{
Leszek Pająk ${ }^{1, *(D)}$, Barbara Tomaszewska ${ }^{1}$, Wiesław Bujakowski ${ }^{2}$, Bogusław Bielec ${ }^{2}$ (D) and \\ Marta Dendys ${ }^{1}$ (D) \\ 1 AGH University of Science and Technology, Mickiewicza 30 Av., 30-059 Kraków, Poland; \\ bts@agh.edu.pl (B.T.); mdendys@agh.edu.pl (M.D.) \\ 2 Mineral and Energy Economy Research Institute, Polish Academy of Sciences, Wybickiego 7A str., \\ 31-261 Kraków, Poland; w.bujakowski@meeri.pl (W.B.); bielec@meeri.pl (B.B.) \\ * Correspondence: pajakl@agh.edu.pl
}

Received: 2 December 2019; Accepted: 4 March 2020; Published: 11 March 2020

\begin{abstract}
The paper presents a review of the geological and hydrogeological data of the Lower Cretaceous aquifer in the Polish Lowlands and discusses the possibilities for the utilisation of geothermal water resources in existing and new district heating systems. Based on experience related to the use of thermal waters in existing geothermal systems, and using data from the literature, assessments have been made of the energy and environmental effects of the application of low-enthalpy geothermal resources from the Lower Cretaceous aquifer as a source of heat for urban district heating systems. The authors concluded that the implementation of such solutions could result in the production of approximately $4 \mathrm{PJ}$ of geothermal energy annually. To date, these resources have only been developed in three locations-Mszczonów, Uniejów and Poddębice-with the total amount of energy generated annually reaching $100 \mathrm{TJ} / \mathrm{year}$. Similar district heating networks in 120 nearby localities have been also identified. Here, specified geological and hydrogeological conditions enable the extraction of heat from the investigated Lower Cretaceous aquifer, with the aim of using this for heating purposes. To achieve this goal, multiple measures are required, including the following: raising public awareness through appropriate education programmes aimed at the youngest school children; systemic, efficient energy management measures at the central, regional and local levels, and providing financial support and ensuring regulations and laws aimed at improving the development of geothermal resources.
\end{abstract}

Keywords: geothermal water; geothermal energy; earth and environmental sciences; district heating; sustainable development; environmental effect

\section{Introduction}

The need to reduce the energy shortfall as well as attempts by various countries to become independent from energy imports were significant driving forces behind the global development of geothermal resources in the 20th century. Since the early 1970s, the United Nations (UN) has played an important role in promoting the exploration and exploitation of these resources [1]. Since then, exploratory work has intensified in various parts of the world [2-5], and numerous innovative research and implementation projects have been undertaken, primarily to produce electricity and heat [6-9]. The global utilisation of geothermal potential is increasing, and new statistical data in this respect have been supplied by Bertani [10] and also Lund and Boyd [11], whose papers have been presented during 
cyclic global conferences. The degree to which water or geothermal resources can be exploited and developed is closely related to local geological and hydrogeological conditions.

In Poland, geothermal energy use for heating purposes was initiated in the final decade of the 20th century $[12,13]$. The experimental stage of the first geothermal plant was commissioned by the Polish Academy of Sciences (MEERI PAS) in the Podhale region in 1992. Since that time, five other plants have been launched. Space heating is a key sector for geothermal energy [12]. This manner of utilising geothermal resources has a special role to play in the context of improving air quality in Poland [14,15]. Here, electricity and heat are produced primarily by burning fossil fuels. Approximately $80 \%$ of electricity is generated by conventional combined heating and power plants fired with hard coal or lignite [16]. This makes measures aimed at the utilisation of renewable energy resources even more important [17-19].

Geothermal energy resources in Poland exhibit heat flux values ranging from 20 to $90 \mathrm{~mW} / \mathrm{m}^{2}$, while geothermal gradients vary from 1 to $4{ }^{\circ} \mathrm{C} / 100 \mathrm{~m}[20,21]$ and are associated with formations of various ages $[3,15,22-26]$. Among the most promising are sedimentary formations in the Polish Lowlands (part of the European Lowlands) which dominate the extensive area spanning from the Baltic Sea coast to the central and southern parts of the country (Figure 1). Their thickness is significant, and they include a considerable share of sandstones and carbonates which contain geothermal resources [21]. In 2018, only five geothermal space heating systems operated in those regions: in Pyrzyce (since 1996), in Mszczonów (since 2000), in Uniejów (since 2001), in Stargard Szczeciński (since 2012, re-opened after closure in 2008) and in Poddębice (since 2012). In three of those systems (in Mszczonów, Uniejów and Poddębice), geothermal energy is produced using a Lower Cretaceous aquifer (Figure 1).

For this reason, it is extremely important to analyse geological and energetic conditions to assess the possibility of using geothermal resources from the Lower Cretaceous to cover the heat requirements of local cities in a large part of Poland.

In this paper, possibilities for the utilisation of Lower Cretaceous geothermal water resources in the Polish Lowlands in existing district heating systems are discussed. These discussions are based on data from the literature and experience related to the use of thermal waters in existing geothermal systems, including the installation operated by Geotermia Mazowiecka SA (joint stock company) localised in Mszczonów (Poland). The company has exploited geothermal water resources in a single-well arrangement for almost 20 years and has achieved favourable effects in terms of the amount of energy produced [22]. 


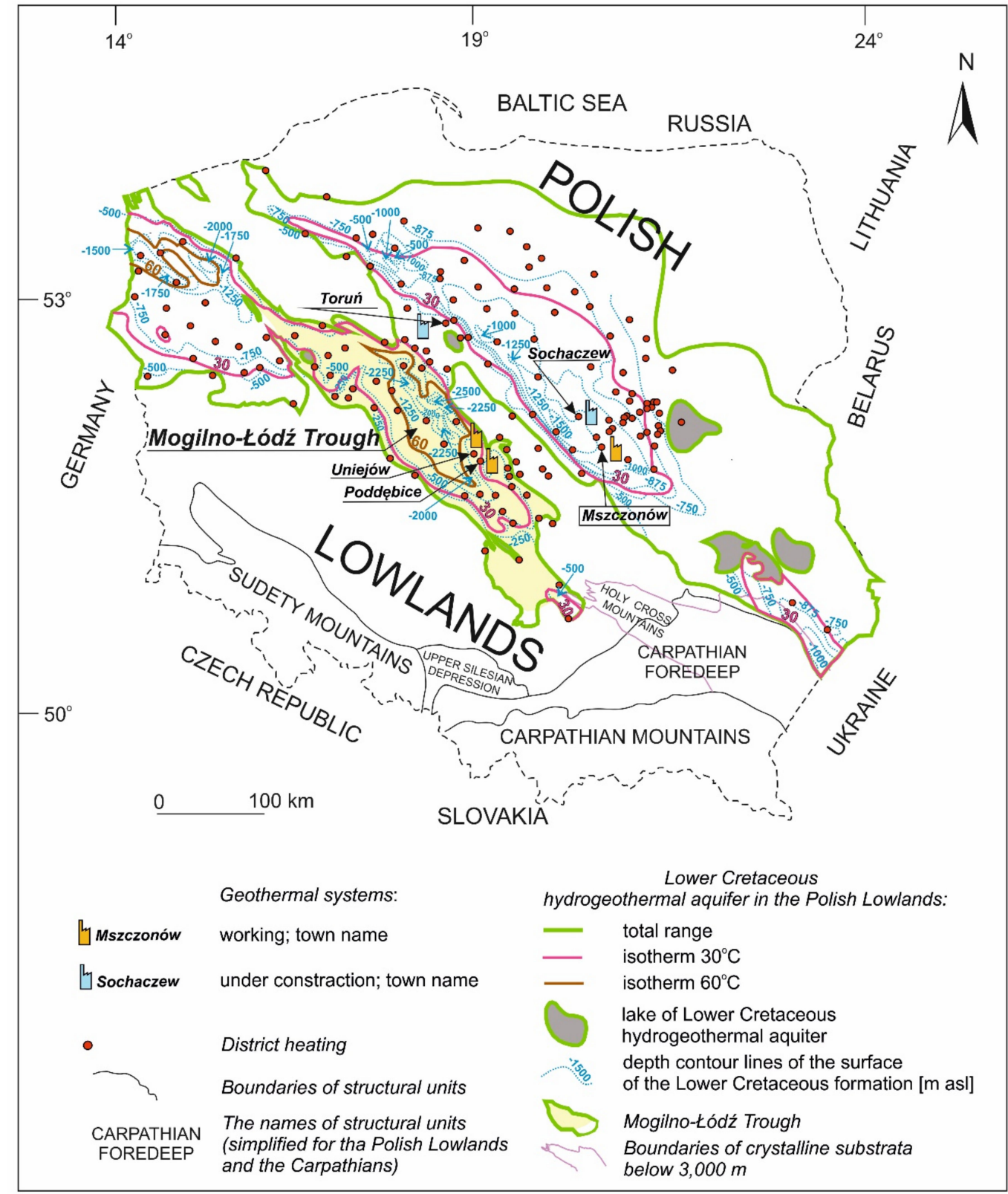

Figure 1. Locations with district heating systems being operated against the background of the boundaries of the Lower Cretaceous hydrogeothermal aquifer in the Polish Lowlands (based on [20,21]).

\section{State of the Art of Lower Cretaceous Geothermal Water Use in Poland}

\subsection{Geological and Hydrological Characteristics of the Lower Cretaceous Aquifer}

Lower Cretaceous aquifers in the Polish Lowlands are reservoir sandstones of the lower Valanginian and/or Aptian and Albian [20]. These form a complex of discontinuous, interspersed sandy, sandy-marly and sandy-mudstone layers with varying permeabilities and with hydraulic contact locally. The aquifer is hydraulically connected both to the underlying Jurassic aquifers and mainly to the underlying carbonate formations of the Upper Cretaceous [23]. The upper boundaries of the Lower Cretaceous formations lie at variable depths, ranging from approximately $250 \mathrm{~m}$ a.s.l. in their southern and northern parts to more than $-2500 \mathrm{~m}$ a.s.l. in their central part [20,23]. Górecki et al. [23] determined that the greatest quantities of geothermal waters are held in the central part of the reservoir, within the so-called Mogilno-Łódź Trough, where the upper boundary of the Lower Cretaceous formations 
usually lies at depths ranging from 400 to $1600 \mathrm{~m}$. The thickness of aquiferous sandstones ranges from 10 to $100 \mathrm{~m}$, but locally-mainly in the aforementioned central part of the aquifer-their thickness may exceed 100 or even $200 \mathrm{~m}$, reaching up to $300 \mathrm{~m}$ in the area of Torun. The effective porosity of Lower Cretaceous sandstones ranges from 3\% to $45 \%$, and most typical values are from $15 \%$ to $25 \%$. Their permeability coefficient range is estimated at $11-4265 \mathrm{mD}$. Szczepański [24] states that the average value of the hydraulic conductivity for Lower Cretaceous deposits, determined on the basis of pumping tests, amounts to $5.41 \times 10^{-5} \mathrm{~m} / \mathrm{s}$. In around half of the central part of the Mogilno-€ódź Trough, the hydraulic conductivity is the highest in relative terms and ranges from $4 \times 10^{-4}$ to $1 \times 10^{-3}$ $\mathrm{m} / \mathrm{s}$ [20]. According to Górecki [20,23], in peripheral areas of the aquifer, low geothermal well flow rates of around $25 \times \mathrm{m}^{3} / \mathrm{h}$ should be expected. High potential well flow rates of above $100 \mathrm{~m}^{3} / \mathrm{h}$ can be expected within the boundaries of the thickest central parts of the structure (the Kujawy-Pomeranian anticlinorium), reaching up to $200 \mathrm{~m}^{3} / \mathrm{h}$, and even $300 \mathrm{~m}^{3} / \mathrm{h}$ locally.

The temperature distribution in the upper layer of the Lower Cretaceous formations indicates that the dominant temperature range is from 20 to $40{ }^{\circ} \mathrm{C}$ [18]. In the Mogilno-Łódź Trough, water temperatures in the Lower Cretaceous range from just a few degrees above the freezing point (near outcrops) to over $80^{\circ} \mathrm{C}$.

The groundwater mineral content of the upper layers of the investigated aquifer differs between its lateral and central parts. In outcrop zones, the water mineral content drops below $2 \mathrm{~g} / \mathrm{L}$ and increases with the direction of water flow and also with depth, reaching $20 \mathrm{~g} / \mathrm{L}$ and even beyond $50 \mathrm{~g} / \mathrm{L}$ locally. The less mineralised Lower Cretaceous groundwaters occur in the most promising areas of the geothermal aquifer, with mineral contents ranging from 1 to $10 \mathrm{~g} / \mathrm{L}$. The Mogilno-Łódź unit includes very thick rock formations within which freshwater flows were detected [27]. Based on geological drilling data, no mineralised water circulation in the axial zone of the synclinorium was detected down to a depth of about 1000-6000 m. In this part, fresh water locally occurred at the upper and lower layers of the Cretaceous aquifer, as well as saline water in the intermediate ones. Moreover, the Lower Cretaceous formation falls in a very extensive zone, where an intense water exchange takes place. This has been revealed to be important for the long-term exploitability of geothermal resources, especially in the case of geothermal water exploitation on the basis of a single production well.

\subsubsection{Characteristics of Hydrogeothermal Conditions in the Mszczonów Area}

Within the Warsaw Trough, fresh geothermal waters (of drinkable water quality) occur in Lower and Middle Albian glauconite sandstones and sands within the Lower Cretaceous aquifer complex; their mineral content is around $0.5-0.6 \mathrm{~g} / \mathrm{L}[28,29]$. The thickness of Lower Cretaceous formations in this area ranges from around 200 to $300 \mathrm{~m}$, and in the well named Mszczonów IG-1, it amounts to $132.5 \mathrm{~m}$ [22]. The water-bearing strata exhibit porosities of around $18 \%$; the values measured in the Mszczonów IG-1 well ranged from 7.28 to $33.09 \%$ [28,30]. Geothermal water is extracted from a depth interval of 1600 to $1700 \mathrm{~m}$ [22], based on a single productive well without the reinjection of cooled geothermal water to the reservoir. The temperature at the wellhead is around $42{ }^{\circ} \mathrm{C}[20,25]$. The nominal geothermal water flux extracted from the Mszczonów IG-1 well averages $45 \mathrm{~m}^{3} / \mathrm{h}$ [22], with approved exploitable resources amounting to $60 \mathrm{~m}^{3} / \mathrm{h}[29,30]$.

\subsubsection{Characteristics of Hydrogeothermal Conditions in the Uniejów Area}

The reservoir rocks which contain geothermal waters in the area of Uniejów are Lower Cretaceous sandstones situated at depths ranging from 1982 to $2084 \mathrm{~m}$ b.g.l.; these waters are extracted using three wells: the Uniejów PIG/AGH-2 productive well, and two wells for reinjection, Uniejów PIG/AGH-1 and Uniejów IGH-1. Approved exploitable resources for the Uniejów PIG/AGH-2 well amount to $120 \mathrm{~m}^{3} / \mathrm{h}$, the water temperature at the wellhead reaches $69.2^{\circ} \mathrm{C}$ and the static pressure under artesian conditions amounts to 2.6 bar [31]. The water exhibits an elevated mineral content ranging from 6.8 to $8.6 \mathrm{~g} / \mathrm{L}$ [32]. The total thickness of the sandstone series from which water is extracted in Uniejów is around $120-150 \mathrm{~m}$. The effective porosity of the sandstone ranges from $12 \%$ to $20 \%$. The parallel 
permeability in the uppermost layer ranges from several dozen to $2000 \mathrm{mD}$, sometimes reaching 3000 $\mathrm{mD}$ and in isolated cases up to $3600 \mathrm{mD}[33,34]$.

\subsubsection{Characteristics of Hydrogeothermal Conditions in the Poddębice Area}

Poddębice is located around $15 \mathrm{~km}$ from Uniejów. Geothermal waters are extracted from depths ranging from 1950 to $2060 \mathrm{~m}$ b.g.l. using the single Poddebice GT-2 production well with a depth of $2101 \mathrm{~m}$. The upper boundary of the Lower Cretaceous formation was reached at the depth of $1962 \mathrm{~m}$ b.g.l., while its lower boundary was reached at $2063 \mathrm{~m}$ b.g.l. The well capacity is $252 \mathrm{~m}^{3} / \mathrm{h}$ at the operating water level of $85.3 \mathrm{~m}$ b.g.l. [35,36], and the water temperature at the wellhead is $68.4^{\circ} \mathrm{C}$. As in Mszczonów, fresh water of the $\mathrm{HCO}_{3}-\mathrm{Na}-\mathrm{Ca}$ type is extracted in Poddębice $(0.4 \mathrm{~g} / \mathrm{L})$, which clearly distinguishes this area from the central part of the Trough, where Na-Cl type waters prevail (e.g., in Uniejów). The Lower Cretaceous aquifer complex in Poddębice is built of grey, fine and medium-grained sandstones which formed on land during the Albian, Aptian and Barremian stages. The upper part of the aquifer exhibits better reservoir parameters with an effective porosity of around 17\%. In the lower part of the profile, below $2027 \mathrm{~m}$ b.g.l., within Lower Cretaceous formations, lens inserts are present, quartz grains become smaller and the porosity drops to $14 \%$. The permeability of the reservoir zone ranges from 87.98 to $1021 \mathrm{mD}$ [36]. The thickness of the sandstone aquifer is $98 \mathrm{~m}$.

\subsection{Operating Geothermal Heating Installations Using Lower Cretaceous Waters}

Within the Polish Lowlands, geothermal energy resources are only produced from the Lower Cretaceous aquifer in three locations (Mszczonów, Uniejów and Poddębice).

\subsubsection{Characteristics of the Mszczonów Geothermal Installation}

The diagram in Figure 2 shows the geothermal installation in Mszczonów. Within the District Heating $(\mathrm{DH})$ system, two parts with different operating temperatures have been distinguished. The first $\mathrm{DH}$ system is the main one, and it operates temperatures ranging from $80 / 60^{\circ} \mathrm{C}$ (supply/return temperature at outdoor temperature $-20^{\circ} \mathrm{C}$ ). The second one is the smallest, and it operates between $70 / 50{ }^{\circ} \mathrm{C}$ (at outdoor temperature $-20^{\circ} \mathrm{C}$ ). In both $\mathrm{DH}$ systems, heat pumps are used: in the main zone, an absorption heat pump with a thermal power of $2.7 \mathrm{MW}$ (driven by 1.9 MW high-temperature natural gas boilers) operates, and a compression heat pump with a thermal power of $1 \mathrm{MW}$ is used in the small circuit.

In addition to heat pumps, the geothermal system uses two boilers driven by high methane content natural gas from the grid with a capacity of $2.3 \mathrm{MW}$ each. The total installed capacity of the heating system in Mszczonów is $8.5 \mathrm{MW}$, and the peak capacity actually used is the same as that in 2017, at 5.8 MW. The amount of energy sold to customers annually is around $40 \mathrm{TJ}$ of which $15 \mathrm{TJ}$ is geothermal energy. Once the energy accumulated in geothermal water has been used, its temperature decreases to $17^{\circ} \mathrm{C}$, leading to effective water cooling within the cascade system assisted by heat pumps. The difference in temperature between the extracted and cooled water $(\Delta \mathrm{T})$ here is ca. $25^{\circ} \mathrm{C}$. The effective geothermal power generated is around 1.3 MW. After treatment, around $40,000 \mathrm{~m}^{3}$ of cooled geothermal water is used annually as drinking water and for other household purposes. However, the largest recipient of geothermal water is the "Termy Mszczonowskie" recreational pool complex, for which $100,000 \mathrm{~m}^{3}$ of geothermal water is extracted annually, and it utilises both the water directly and the energy accumulated therein. The geothermal installation has covered building energy needs since 2000 [37]. During this operation period of slightly less than 20 years, no significant downtime was recorded. Geothermal heat is used in all apartment buildings managed by the housing cooperative in Mszczonów as well as in most public buildings, including the primary school, kindergarten, cultural centre, sports hall and clinic. 


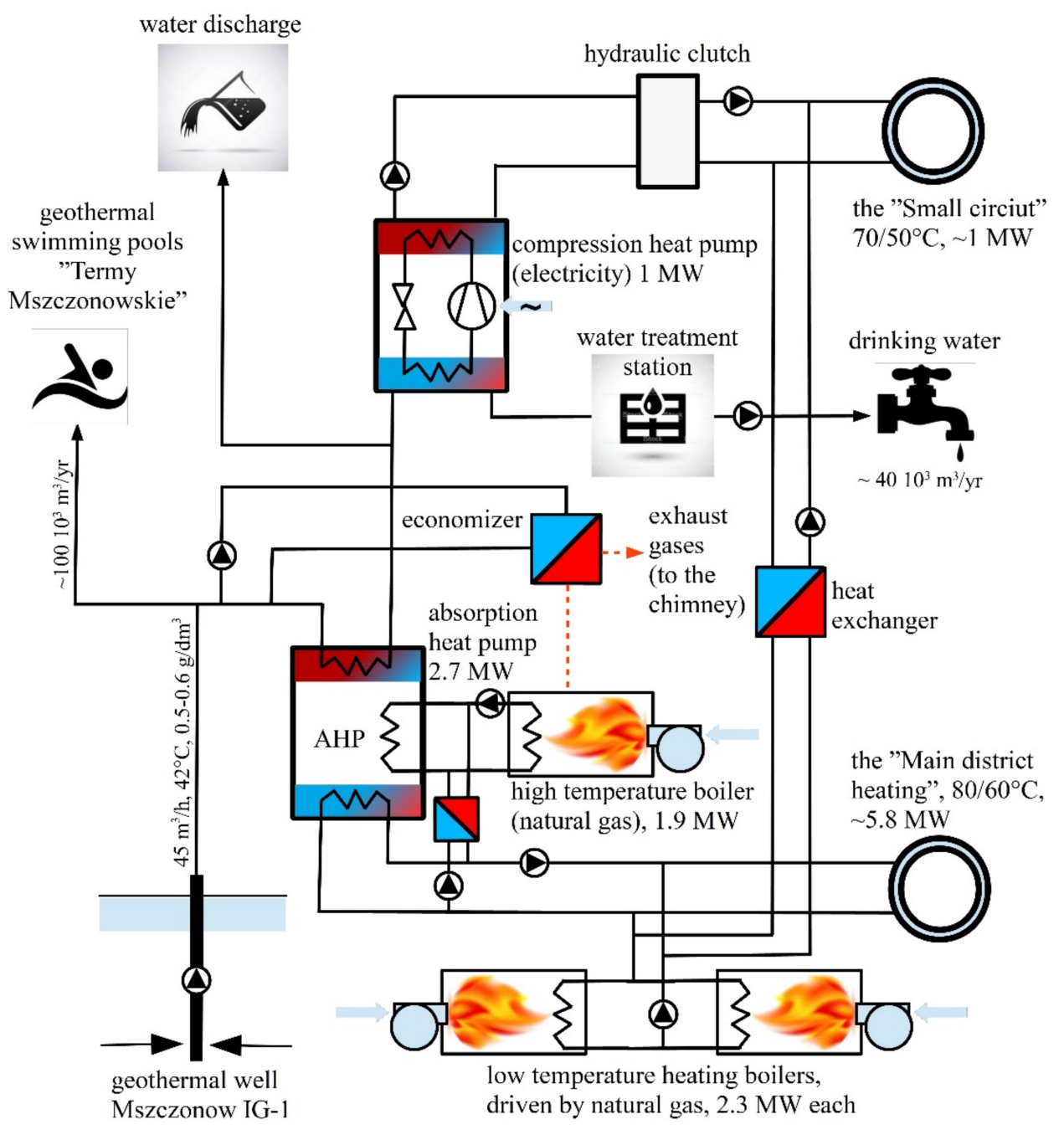

Figure 2. Diagram of the geothermal installation in Mszczonów.

\subsubsection{Characteristics of the Uniejów Geothermal Installation}

The total thermal capacity installed in Uniejów amounts to $7.4 \mathrm{MW}$, including $3.2 \mathrm{MW}$ of geothermal capacity [38], 1.8 MW from the biomass-fired peak load boiler and 2.4 MW from oil-fired peak load boilers, which currently serve as a reserve. The district heating installation supplies heat to around $80 \%$ of buildings in Uniejów. The district heating network in Uniejów is $13 \mathrm{~km}$ long [39]. It is made of pre-insulated pipes suitable for $70 / 35^{\circ} \mathrm{C}$ heating water parameters. The production of domestic hot water for both residential and public facilities is centralised. Two two-stage heat exchangers are responsible for supplying hot water [39]. Heat exchangers may also be located in the recipient's compact nodes. The district heating system covers public buildings, tourist and sport facilities (e.g., the football pitch complex), companies, residential buildings (around 70\% of all residents within town limits), the thermal and swimming pool complex, hotels, conference centre and restaurants. The water within the system is supplied to customers by means of circulation pumps. These pumps operate under a continuous control system and have a combined capacity of $360 \mathrm{~m}^{3} / \mathrm{h}$. The entire heating system is controlled and monitored by an integrated computer system which facilitates operation and reduces energy losses [39]. Annual geothermal energy sales are estimated at 40 TJ. Apart from the use of the water for district heating purposes, it is also utilised for balneological and recreational purposes in the "Termy Uniejów" pool complex. 


\subsubsection{Characteristics of the Poddębice Geothermal Installation}

The capacity of the Poddebice geothermal heating system is about 5.4 MW [36]. The installation is operated by Geotermia Poddębice Sp. z o.o. (limited liability company). The extraction of geothermal water is conducted in a single-well arrangement without reinjection (cooled water is dumped in the Ner River). Geothermal water has a low mineral content and could be used as drinking water. To date, however, only heat has been extracted, with only a very small amount of water used as drinking water. The operating parameters observed are $\sim 80 / \sim 55^{\circ} \mathrm{C}$ [36]. The amount of heat sold to the users is estimated at $48 \mathrm{TJ} /$ year.

\section{Geothermics as Environmentally Friendly Heating Systems}

\subsection{Available Geothermal Resources}

It should be noted that the extraction of geothermal water is based on the approved amount of exploitable resources under defined geological, hydrogeological, and structural conditions, which have been confirmed by hydrodynamic tests. This amount allows geothermal energy resources to be estimated, because water is the carrier of this energy. These values are variable, but-as has been indicated - the real capacities of Lower Cretaceous geothermal wells in Poland range from $25 \mathrm{~m}^{3} / \mathrm{h}$ in peripheral zones to as much as over $300 \mathrm{~m}^{3} / \mathrm{h}$ locally in the central parts of the aquifer. These capacities differ between the investigated DH networks $\left(60 \mathrm{~m}^{3} / \mathrm{h}\right.$ in Mszczonow, $120 \mathrm{~m}^{3} / \mathrm{h}$ in Uniejov, $252 \mathrm{~m}^{3} / \mathrm{h}$ in Poddębice), confirming a significant source of geothermal waters with wellhead temperatures of $42^{\circ} \mathrm{C}$, $69.2^{\circ} \mathrm{C}$ and $68.4{ }^{\circ} \mathrm{C}$, respectively.

The Lower Cretaceous aquifer covers an area of $127,872.60 \mathrm{~km}^{2}$. The first scientists in Poland who estimated static and exploitable resources in Poland for the considered Lower Cretaceous were Górecki et al. [20]; the estimation of considered geothermal energy resources was based upon the EU standards [40,41].

Static resources are defined as the amount of thermal energy stored in rocks and within the free (gravitational) geothermal water which is present in pores, fissures or caverns of the hydrogeothermal level in question. The following formula was adopted for the calculation [20]:

$$
E_{S R}=A \cdot m_{p} \cdot\left[\left(1-p_{e}\right) \cdot p_{s} \cdot c_{S}+p_{s}+p_{e} \cdot p_{w} \cdot c_{w}\right] \cdot\left(T_{s}-T_{o}\right)[\mathrm{J}]
$$

where

- $\quad m_{p}$-cumulative thickness of groundwater horizons in the reservoir [m];

- $\quad p_{e}$-effective porosity [-];

- $T_{s}$-temperature at the top surface of the groundwater reservoir $\left[{ }^{\circ} \mathrm{C}\right]$;

- $T_{0}$-mean annual temperature at the Earth's surface $\left[{ }^{\circ} \mathrm{C}\right]$;

- $\quad p_{s}$ and $p_{w}$-mean density of the rock framework and water, respectively $\left[\mathrm{kg} / \mathrm{m}^{3}\right]$;

- $\quad c_{S}$ and $c_{w}$-mean specific heat of the rock framework and water, respectively $\left[\mathrm{J} / \mathrm{kg}{ }^{\circ} \mathrm{C}\right]$;

- $A$-area of the calculation block $\left[\mathrm{m}^{2}\right]$.

The estimated static resources accumulated in the Lower Cretaceous waters and rocks are $4.23 \cdot 10^{20} \mathrm{~J}$.

The exploitable resources (safe yield) are understood as the amount of free (gravitational) geothermal water within the hydrogeothermal level, but without indicating the detailed locations and technical and economic parameters of water extraction. The exploitable resources are expressed in $\mathrm{m}^{3} / \mathrm{h}$ at relevant drawdown, and afterwards they are recalculated to J/year. The exploitable resources are assessed based upon the results of all hydrogeothermal studies and tests made in exploration and production wells mentioned in Section 2 and are determined for a single production well or for a cluster of wells. Exploitable resources (safe yield), which amount to $3.95 \cdot 10^{17}$ J per year, are found 
within the area of $24,235.84 \mathrm{~km}^{2}$; i.e., $18.95 \%$ of the total area of the Lower Cretaceous aquifer within the Polish Lowlands [42].

\subsection{Conditions for Geothermal Installations}

To date, only three geothermal installations have been commissioned which produce heat from Lower Cretaceous geothermal waters; one such installation, in Sochaczew, is under construction (Figure 1). However, as indicated in Figure 1, there are about 120 towns and cities within the boundaries of the geothermal aquifer in question, in which district heating network systems were constructed in the past to supply residents with heat and hot water. These systems use heat generated from conventional energy sources. Slightly less than 100 towns and cities are located within the boundaries of the identified geothermal water resources, where the temperatures of the uppermost layer of the Lower Cretaceous reservoir are around $30^{\circ} \mathrm{C}$. Moreover, about a dozen of these are located where waters have the same values of Poddębice and Uniejów reservoirs. This demonstrates the huge potential of low-enthalpy geothermal energy resources as an alternative and environmentally friendly source of heat which will improve air quality and the residents' living conditions.

In case of the Lower Cretaceous geothermal resources considered, it was recognised that the temperature at the wellhead (documented as $71-41{ }^{\circ} \mathrm{C}$ ) is $-50{ }^{\circ} \mathrm{C}$ on average and cools to $20^{\circ} \mathrm{C}$. The water flow (documented at $295-60 \mathrm{~m}^{3} / \mathrm{h}$ ) is $-150 \mathrm{~m}^{3} / \mathrm{h}$ on average. The average installed capacity utilization factor is -0.3 (for heating and domestic water). Thus, one installation from 100 potential locations is able to generate about $40 \mathrm{TJ} /$ year of energy. Assuming theoretically the use of this energy in the 100 mentioned locations, the potential geothermal energy resources generated can be estimated at $4 \mathrm{PJ} /$ year. That is why the implementation of geothermal heating solutions in the locations is so important.

Typical operating temperatures for district heating systems, used for heating of residential buildings in Poland can be summarized as follows:

- $130 / 65{ }^{\circ} \mathrm{C}$ (where the first temperature corresponds to the supply temperature, while the second to the return temperature) for large district heating systems;

- $\quad 90 / 70{ }^{\circ} \mathrm{C}$ for small local systems.

The authors' experience has shown that the above parameters are often excessive; examples of operating geothermal installations in Mszczonów (DH network temperatures between 50 and $70{ }^{\circ} \mathrm{C}$ ), in Uniejów $\left(70 / 35^{\circ} \mathrm{C}\right.$ network parameters) or in Poddębice $\left(80 / 55^{\circ} \mathrm{C}\right.$ network parameters) demonstrate that they could be operated at lower temperatures, allowing for greater efficiency. In many cases, this requires a thermal efficiency improvement of some buildings, aimed at obtaining the requested energy needs. In the summer period, temperature parameters of the district heating network are usually around $65 / 30{ }^{\circ} \mathrm{C}$. The temperature of the supplied hot water must range from 55 to $60^{\circ} \mathrm{C}$ according to the Journal of Laws [43]. Since the temperatures of the Lower Cretaceous horizon range from 20 to $80{ }^{\circ} \mathrm{C}$, the use of heat pumps and peak load boilers in installations could be more profitable in many cases. Regarding peak load boilers, an environmentally friendly solution is the construction of a system integrated with biomass-fired boilers, since a significant amount of the available biomass resources in Poland-integrated systems consisting of biomass-fired boilers-represents an environmentally friendly solution [44]. Such a solution was implemented at Geotermia Uniejów.

\subsection{Important Environmental Aspects}

The use of geothermal energy in the installations described in this paper contributes to improving air quality locally and enables the consumption of conventional energy carriers to be reduced. In the case of Mszczonów, reductions in pollutant emissions into the atmosphere due to the use of geothermal energy are estimated as follows [22]:

- A total of $48 \mathrm{~kg} /$ year $\mathrm{SO}_{2}$ for natural gas as a reference fuel and $23.8 \times 10^{3} \mathrm{~kg} /$ year for hard coal; 
- In the case of $\mathrm{CO}_{2}$, emissions of $1200 \times 10^{3} \mathrm{~kg} /$ year for natural gas and $3027 \times 10^{3} \mathrm{~kg} /$ year for hard coal are avoided.

The reduction in emissions in the case of Poddębice is estimated as follows:

- In total, $35 \times 10^{3} \mathrm{~kg} /$ year $\mathrm{SO}_{2}$ for coal as a reference fuel;

- In total, $5000 \times 10^{3} \mathrm{~kg} /$ year $\mathrm{CO}_{2}$ for coal as a reference fuel, and $2900 \times 10^{3} \mathrm{~kg} /$ year $\mathrm{CO}_{2}$ for natural gas as a reference fuel.

The reduction of pollutants estimated above was calculated based on factors suitable for selected fuels and types of energy sources. The values are provided by the National Centre for Emissions Management (KOBiZE). The values of emission factors are summarised in Table 1.

Table 1. Emission factors for selected fuels and types of energy sources [45].

\begin{tabular}{|c|c|c|}
\hline Pollutant Name & $\begin{array}{c}\text { Hard Coal, Heating Power } P \text { in } \\
\text { the Range } 500 \mathrm{~kW}<P \leq 5 \mathrm{MW} \text {, } \\
\text { Natural Chimney Draft } \\
{\left[\mathrm{g} / 10^{3} \mathrm{~kg}\right]}\end{array}$ & $\begin{array}{l}\text { Natural Gas, Heating Power } P \text { in } \\
\text { the Range of } 500 \mathrm{~kW}<P \leq 5 \mathrm{MW} \\
\qquad\left[\mathrm{g} / \mathrm{m}^{3}\right]\end{array}$ \\
\hline $\mathrm{SOx} / \mathrm{SO}_{2}$ & $16,000 \mathrm{shc}$ & $0.002 \mathrm{~s}_{\mathrm{ng}}$ \\
\hline $\mathrm{NOx} / \mathrm{NO}_{2}$ & 1000 & 1.75 \\
\hline $\mathrm{CO}$ & 45,000 & 0.24 \\
\hline $\mathrm{CO}_{2}$ & 2106 & 2000 \\
\hline Total suspended participants (TSP) & $1500 \mathrm{~A}_{\mathrm{hc}}$ & 0.0005 \\
\hline $\mathrm{B}(\mathrm{A}) \mathrm{P}$ & 14 & 0 \\
\hline
\end{tabular}

where $\mathrm{s}_{\mathrm{hc}}$ is the hard coal sulfur content [\%] (the typical value for Polish coal is assumed to be $1 \%$ ), $\mathrm{S}_{\mathrm{ng}}$ is the natural gas total sulfur content $\left[\mathrm{mg} / \mathrm{m}^{3}\right]$ (the typical value for Polish network natural gas is assumed to be $40 \mathrm{mg} / \mathrm{m}^{3}$ ), and $A_{\mathrm{hc}}$ is the hard coal ash content [\%] (the typical value for Polish good quality hard coal is assumed to be $10 \%$ ). Assumed common values of the gross caloric values of fuels are as follows: hard coal, $27 \mathrm{MJ} / \mathrm{kg}$; natural gas (high methane content- the E-type natural gas according to the national nomenclature), $35.5 \mathrm{MJ} / \mathrm{m}^{3}$.

The reduction of pollutant emissions in Poddebice is greater than that achieved in Mszczonów despite the similar amounts of energy produced by the installations. This is due to the higher temperature of the geothermal water extracted in Poddebice and to the operational phase without the use of heat pumps, as well as to the very short operating time of peak load boilers.

In the case of Uniejów, reductions in emissions are estimated (based on Table 1) at ca. $28 \mathrm{Mg} /$ year $\mathrm{SO}_{2}$ and $4188 \mathrm{Mg} /$ year $\mathrm{CO}_{2}$ for coal as a reference fuel, and $2418 \mathrm{Mg} /$ year $\mathrm{CO}_{2}$ for natural gas as a reference fuel.

Given the fact that around $80 \%$ of thermal energy in Poland is produced by burning hard coal [16] and the energy obtained from natural gas accounts for less than $8 \%$ [16], the reductions resulting from the use of geothermal energy should be calculated in comparison to the emission values typical of hard coal.

Improving air quality and fighting smog are possible through systemic, efficient energy management measures at the central, regional and local levels. According to [46], these measures must also be supported by appropriate financial support as well as relevant regulations and laws. Examples of good practice in this area may be found in the experience of France and Germany [47].

After Bulgaria, Poland is one of the top ten countries in Europe with the most polluted air [48,49]. During air quality monitoring conducted at 123 urban and suburban measurement stations in Poland with measurement series covering at least $85 \%$ of days in the year, air quality standards were exceeded more than 75 times at $77 \%$ of measurement stations (Central Inspectorate of Environmental Protection 
2016). Poor air quality is mostly caused by the burning of fossil fuels, which mainly comprises coal in small district boilers or at the users' homes.

\subsection{Important Economic Aspects}

Geothermal energy in the economic sphere (the costs of energy production) is often compared with coal in Poland. The costs of energy production based on coal are usually lower than the costs of energy from geothermal energy. Current trends are aimed at the gradual elimination of coal-based energy sources; their transformation into other energy carriers seems to be assured in Poland, at least in terms of small and medium heat sources (up to several MW). Geothermal energy represents a good alternative in this area; however, the high level of investment expenditure affects the cost of energy production. Other energy carriers require higher operating costs. Reservoir conditions and district heating demand allow us to determine the total cost of energy production without heat pumps based on geothermal energy, which can be compared with natural gas and even coal [50].

\section{Prospectives for Geothermal Energy in Poland}

Promoting the use of renewable energy sources is among the key mechanisms which can be used to disseminate environmentally friendly energy solutions. Another important factor is raising public awareness through appropriate education programmes aimed at the youngest school children [51], as well as through projects whose stakeholders are adults [46,49]. Such measures have been taken at all of the locations analysed. In Mszczonów, Uniejów and Poddębice, the entrepreneurs who operate geothermal installations focus not only on providing environmentally friendly energy and on the local environment, but also on educating both residents and tourists who visit these towns. Geothermal plants can be visited on guided tours, during which the main elements of the geothermal system are presented and the value of investing in geothermal energy is discussed. Companies participate also in numerous international and local scientific projects, promoting the use of geothermal energy in Poland. In Uniejov, a series of comic books ("Welcome to the Thermal Town of Uniejów" and "Uniejów Spa-in Harmony with Nature") devoted to geothermal energy are offered to the youngest visitors; i.e., primary school students. Additionally, to raise the environmental awareness of inhabitants of the Łódź Province, Geotermia Uniejów runs an educational project entitled "Geothermal Energy with Class". Using a grant from the Provincial Fund for Environmental Protection and Water Management in Łódź, it publishes educational and promotional materials (e.g., the "Geothermal Wealth" brochure) and holds a series of lectures for school students entitled "the utilisation of geothermal waters in Uniejów Spa" [39]. These lectures are given at 45 schools in the city of Łódź and in all districts within the province. The effects of this educational campaign can be assessed during the school competition "Why and how to save water?", in which the reward for winners is a trip to Uniejów [39].

\section{Conclusions}

The amount of available energy resources globally varies depending on multiple geological and hydrogeological parameters. Given the current level of technological development and global experience, it is obvious that the use of low-temperature resources may be of significant economic and environmental importance. To date, these resources have only been developed in three locations, with the total amount of energy generated annually reaching $100 \mathrm{TJ} /$ year. Similar infrastructure conditions as those in existing district heating networks have been identified in around 120 towns and cities whose location enables the extraction of heat from the aquifer in question for space heating purposes. The implementation of such solutions could result in the production of $4 \mathrm{PJ}$ of geothermal energy annually. In order to achieve this goal, multiple measures are required, including the following:

- Raising public awareness through appropriate education programmes aimed at the youngest school children;

- Systemic, efficient energy management measures at the central, regional and local levels; 
- Providing financial support and ensuring that regulations and laws are conducive to the development of geothermal resources.

The environmental impact in Poddębice is slightly better than that achieved in Mszczonów despite the similar amounts of energy produced by the installations in Mszczonów and in Poddębice. This is due to the higher temperature of the geothermal water extracted in Poddebice and the fact that the installation there operates without the use of heat pumps; furthermore, the operating time of the peak load boilers is also very short.

We hope that our considerations regarding the development of geothermal heating systems based on the use of Lower Cretaceous water potential in Poland will be reflected in investment projects. This solution would undoubtedly help to improve air quality in many parts of the country.

Author Contributions: Conceptualization, B.T. and W.B.; methodology, B.T. and L.P.; software, L.P.; validation, B.T. and L.P., formal analysis, B.T.; investigation, W.B.; resources, B.T. and B.B.; data curation, B.T., M.D. and L.P.; writing-original draft preparation, B.T. and L.P.; writing—review and editing, B.T.; visualization, L.P., M.D. and B.B. All authors have read and agreed to the published version of the manuscript

Funding: This research was partly funded by the Polish National Centre for Research and Development (Project No. POLTUR2/1/2017) and AGH Project No. 16.16.140.315.

Conflicts of Interest: The authors declare no conflicts of interest.

\section{References}

1. Dowgiałło, J. Geologia i wykorzystanie energetyczne zasobów geotermicznych we włoszech. Przeglad Geol. 1972, 20, 109-113.

2. Wang, X.; Wang, G.I.; Gan, H.N.; Liu, Z.; Nan, D.W. Hydrochemical characteristics and evolution of geothermal fluids in the Chabu high-temperature geothermal system, Southern Tibet. Geofluids 2018, 2018, 8532840. [CrossRef]

3. Sowiżdżał, A.; Kaczmarczyk, M. Analysis of thermal parameters of Triassic, Permian and Carboniferous sedimentary rocks in central Poland. Geol. J. 2016, 51, 65-76. [CrossRef]

4. Śliwa, T.; Kruszewski, M.; Zare, A.; Adssadi, M.; Sapińska-Śliwa, A. Potential application of vacuum insulated tubing for deep borehole heat exchangers. Geothermics 2018, 75, 58-67. [CrossRef]

5. Tomaszewska, B.; Bundschuh, J.; Pająk, L.; Dendys, M.; Delgado Quezada, V.; Bodzek, M.; Armienta, A.A.; Ormachea Munioz, M.; Kasztelewicz, A. Use of low-enthalpy and waste geothermal energy sources to solve arsenic problems in freshwater production in selected regions of Latin America using a process membrane distillation-research into model solutions. Sci. Total Environ. 2020, 714, 136853. [CrossRef] [PubMed]

6. Morales-Arredondo, I.; Armienta, M.A.; Segovia, N. Groundwater chemistry and overpressure evidences in cerro prieto geothermal field. Geofluids 2017, 2017, 2395730. [CrossRef]

7. Kaczmarczyk, M. Impact of rock mass temperature on potential power and electricity generation in the ORC installation. In Proceedings of the E3Web of Conferences, Kraków, Poland, 25-27 September 2017; Volume 24. Article number 02007.

8. Wu, B.; Ma, T.; Feng, G.; Chen, Z.; Zhang, X. An approximate solution for predicting the heat extraction and preventing heat loss from a closed-loop geothermal reservoir. Geofluids 2017, 2017, 2041072. [CrossRef]

9. Bakhsh, K.J.; Nakagawa, M.; Arshad, M.; Dunnington, L. On heat and mass transfer within thermally shocked region of enhanced geothermal system. Geofluids 2017, 2017, 2759267.

10. Bertani, R. Geothermal power generation in the world 2010-2014 update report. In Proceedings of the World Geothermal Congress 2015, Melbourne, Australia, 19-25 April 2015.

11. Lund, J.W.; Boyd, T.L. Direct utilization of geothermal energy 2015: Worldwide review. In Proceedings of the World Geothermal Congress 2015, Melbourne, Australia, 19-25 April 2015.

12. Kepińska, B. Geothermal energy country update report from Poland, 2010-2014. In Proceedings of the World Geothermal Congress 2015, Melbourne, Australia, 19-25 April 2015.

13. Bujakowski, W.; Barbacki, A.; Miecznik, M.; Pajak, L.; Skrzypczak, R. A structural-thermal model of the Karkonosze Pluton (Sudetes Mountains, SW Poland) for Hot Dry Rock (HDR) geothermal use. Arch. Min. Sci. 2016, 61, 917-935. [CrossRef] 
14. Szulc, A.; Tomaszewska, B. Perspectives on the use of geothermal heat pump systems to reduce low emitted air pollutants in the health resort areas. In Proceedings of the E3Web of Conferences, Pune, India, 18-20 December 2019; Volume 116. Article number 00087.

15. Kaczmarczyk, M.; Sowiżdżał, A.; Tomaszewska, B. Energetic and environmental aspects of individual heat generation for sustainable development at a local scale-A case study from Poland. Energies 2020, 13, 454. [CrossRef]

16. Buńczyk, A. Energetyka Cieplna W Liczbach—2016; Urząd Regulacji Energetyki: Warszawa, Poland, 2017; p. 97.

17. Operacz, A.; Wałega, A.; Cupak, A.; Tomaszewska, B. The comparison for investment in Poland or river protection? J. Clean. Prod. 2018, 2018, 575-592. [CrossRef]

18. Operacz, A. The term "effective hydropower potential", based on sustainable development-An initial case study of the Raba River in Poland. Renew. Sustain. Energy Rev. 2017, 75, 1453-1463. [CrossRef]

19. Operacz, A.; Tomaszewska, B. The review of Polish formal and legal aspects related to hydropower plants. Environ. Sci. Pollut. Res. 2016, 23, 18953-18959. [CrossRef] [PubMed]

20. Górecki, W. Atlas Zasobów Geotermalnych Formacji Mezozoicznych Na Niżu Polskim; Wyd. GOLDRUK: Kraków, Poland, 2006.

21. Sowiżdżał, A. Geothermal energy resources in Poland-Overview of the current state of knowledge. Renew. Sustain. Energy Rev. 2018, 82, 4020-4027. [CrossRef]

22. Bujakowski, W.; Balcer, M.; Barbacki, A.P.; Bielec, B.; Tomaszewska, B.; Pająk, L.; Skrzypczak, R.; Dendys, M.; Kasztelewicz, A.; Dajek, B.K. Otwór Geotermalny Mszczonów IG-1 Rekonstrukcja I Wieloletnia Eksploatacja (Mszczonów IG-1 Geothermal Well Reconstruction and Long-Time Exploitation-In Polish); Wydawnictwo IGSMiE PAN(PAS MEERI Published): Kraków, Poland, 2017.

23. Górecki, W.; Hajto, M.; Strzetelski, W.; Szczepański, A. Dolnokredowy oraz dolnojurajski zbiornik wód geotermalnych na Niżu Polskim. Przeglad Geol. 2010, 58, 589-593.

24. Szczepański, A. Warunki hydrogeologiczne dolnojurajskiego I dolnokredowego zbiornika wód geotermalnego. In Atlas Wód Geotermalnych Niżu Polskiego; Górecki, W., Ed.; Wydawnictwa AGH: Kraków, Poland, 1990.

25. Sowiżdżał, A.; Chmielowska, A.; Tomaszewska, B.; Operacz, A.; Chowaniec, J. Could geothermal water and Energy use improve living conditions?. Environmental effects from Poland. Arch. Environ. Prot. 2019, 45, 109-118.

26. Kaczmarczyk, M. Potential of existing and newly designed geothermal heating plants in limiting of low emissions in Poland. In Proceedings of the E3S Web of Conferences, Berdiansk, Ukraine, 4-8 September 2018; Volume 44, p. 00062.

27. Dowgiałło, J. Prowincja platformy paleozoicznej. In Hydrogeologia Regionalna Polski Tom II-Wody Mineralne, Lecznicze I Termalne Oraz Kopalniane; Paczyński, B., Sadurski, A., Eds.; Państwowy Instytut Geologiczny: Warszawa, Poland, 2007; pp. 38-56.

28. Bujakowski, W. Dokumentacja Powykonawcza Z Prac Badawczo-Rozwojowych—Dostosowanie Otworu Mszczonów IG-1 Dla Potrzeb Eksploatacji Złoża Geotermalnego Do Systemu Grzewczego; IGSMiE PAN (Archiwum): Kraków, Poland, 1999; (unpublished).

29. Tomaszewska, B. Warunki hydrogeotermalne w rejonie mszczonowa. Geol. Explor. Technol. Geotherm. Sustain. Dev. 2015, 2015, 81-94.

30. Bujakowski, W. Pierwsza W Polsce Rekonstrukcja Głębokiego Otworu Wiertniczego Mszczonów IG-1 Do Celów Ciepłowniczych; Wyd. IGSMiE PAN: Kraków, Poland, 2001.

31. Kępińska, B.; Bujakowski, W. Wytyczne Projektowe Poprawy Chłonności Skał Zbiornikowych W Zwiazku Z Zatłaczaniem Wód Termalnych W Polskich Zakładach Geotermalnych; Wyd. EJB: Kraków, Poland, 2011.

32. Tomaszewska, B.; Rajca, M.; Kmiecik, E.; Bodzek, M.; Bujakowski, W.; Wator, K.; Tyszer, M. The influence of selected factors on the effectiveness of pre-treatment of geothermal water during the nanofiltration process. Desalination 2017, 406, 74-82. [CrossRef]

33. Bojarski, L.; Sokołowski, A. Dokumentacja Zasobów Wód Termalnych W Kat. C I B Z Utworów Kredy Dolnej Rejonu Uniejowa; PIG Architekci: Warszawa, Poland, 1991 (unpublished). 
34. Bentkowski, A.; Biernat, H.; Kapuściński, J.; Posyniak, A. Dodatek Do Dokumentacji Ustalajacej Zasoby Eksploatacyjne Wód Termalnych Z Utworów Kredy Dolnej Rejonu Uniejowa Wraz Z Określeniem Warunków Hydro-Geologicznych W Związku Z Wtłaczaniem Wód Do Dolnokredowego Poziomu Wodonośnego; Opr. Przedsiębiorstwo Geologiczne „Polgeol” SA. Arch. Geotermia Uniejów Sp. z o.o.: Uniejów, Poland, 2005 (unpublished).

35. Kępińska, B. Przegląd stanu wykorzystania energii geotermalnej w Polsce w latach 2013-2015. Geol. Explor. Technol. Geotherm. Sustain. Dev. 2016, 2016, 19-35.

36. Kępińska, B. Geothermal Energy Utylisation Potential in Poland-Town Poddębice. Study Visits' Report; Project EOG: Kraków, Poland, 2017; No 115/2016/Wn05/OA-XN-04/D.

37. Balcer, M. Geotermia Mazowiecka-Historia, teraźniejszość, przyszłość. Geol. Explor. Technol. Geotherm. Sustain. Dev. 2015, 2015, 9-16.

38. Bujakowski, W. The use of geothermal waters in Poland (state in 2009). PrzegladGeologiczny 2010, 58, 580-588.

39. Geotermia. Available online: http://geotermia-uniejow.pl/ (accessed on 10 October 2019).

40. Haenel, R.; Staroste, E. Atlas of geothermal resources in the European Community, Austria and Switzerland; The Schafer: Hannover, Germany, 1988; p. 74, 110 plates.

41. Haenel, R.; Hurter, S. Atlas of Geothermal Resources in Europe; Office for the Official Publications of the European Communities: Brussels, Belgium, 2002.

42. Górecki, W.; Sowiżdżał, A.; Hajto, M.; Wachowicz-Pyzik, A. Atlases of geothermal waters and energy resources in Poland. Environ. Earth Sci. 2015, 74, 7487-7495. [CrossRef]

43. Rozporzadzenie Ministra Infrastruktury I Budownictwa Z Dnia 14 Listopada 2017 R. Zmieniajace Rozporzadzenie W Sprawie Warunków Technicznych, Jakim Powinny Odpowiadać Budynki I Ich Usytuowanie; Dziennik Ustaw Poz. 2285 z 2017 roku: Warszawa, Poland, 2017.

44. Bujakowski, W.; Pająk, L.; Tomaszewska, B. Zasoby energii odnawialnej w województwie ślaskim oraz możliwości ich wykorzystania. Miner. Resour. Manag. 2008, 24, 409-426.

45. The National Center for Emissions Management KOBiZE. Wskaźniki Emisji Zanieczyszczeń Ze Spalania Paliw, Kotty O Mocy Nominalnej Do 5 MW (Indicators of Pollutant Emissions from Fuel Combustion, Boilers with a Nominal Power of up to $5 \mathrm{MW}$, In Polish); The National Center for Emissions Management KOBiZE: Warszawa, Poland, 2015.

46. Tomaszewska, B.; Kasztelewicz, A.; Dendys, M.; Bujakowski, W.; Rahner, S.; Hartmann, M.; Weinreich, J. European educational concept in environmental, nature- and climate protection to safeguard a cross border sustainable development. In Proceedings of the E3S Web of Conferences, Berdiansk, Ukraine, 4-8 September 2018; Volume 66. no 03005.

47. Kępińska, B.; Tomaszewska, B. Main barriers for geothermal energy development in Poland. Proposals of changes. Przeglad Geologiczny 2010, 58, 594-598.

48. European Environment Agency. Air Quality in Europe-2017 Report; EEA Report, No. 13/2017; EEA: Coprnhagen, Denmark, 2017; ISBN 978-92-9213-921-6.

49. Rahner, S.; Winter, I.; Hartmann, M.; Wittich, F.; Kasztelewicz, A.; Tomaszewska, B.; Pajak, L.; Dendys, M.; Operacz, A.; Mraz, M.; et al. Study on national activities and funding opportunities of furthering education programs for unemployed academics. In Proceedings of the E3S Web of Conferences, Berdiansk, Ukraine, 4-8 September 2018; Volume 66. no 03004.

50. Pająk, L.; Bujakowski, W. Zmiany ceny zakupu energii cieplnej pochodzacej z polskich ciepłowni geotermalnych w latach 2007-2018 w świetle obowiązujacych taryf rozliczeniowych (Changes in the purchase price of heat originating from Polish geothermal heating plants in the time period 2007-2018 based on settlement tariffs-in Polish, tables and figures in English). Geol. Explor. Technol. Geotherm. Energy Sustain. Dev. 2018, 1, 29-35.

51. Ocetkiewicz, I.; Tomaszewska, B.; Mróz, A. Renewable energy in education for sustainable development. The Polish experience. Renew. Sustain. Energy Rev. 2017, 80, 92-97. [CrossRef]

(C) 2020 by the authors. Licensee MDPI, Basel, Switzerland. This article is an open access article distributed under the terms and conditions of the Creative Commons Attribution (CC BY) license (http://creativecommons.org/licenses/by/4.0/). 